$\mathrm{Ma} \mathrm{Li}{ }^{1}$, Ahmed Alduais ${ }^{2}$

\title{
A STUDY ON LEARNING STYLES AND THEIR POSSIBLE EFFECT ON ACADEMIC PERFORMANCE AMONG UNIVERSITY STUDENTS IN GLASGOW
}

\author{
1) XUE Bang Education \\ Academic Research and Development Centre, K12 Department \\ Beijing, P.R. China, No. 19 Xinjiekou Wai St., 100875, Beijing, P.R.China \\ liangmuchengmiki@163.com \\ 2) Institute of International \& Comparative Education \\ Faculty of Education, Beijing Normal University (BNU) \\ Beijing, P.R. China \\ ibnalduais@gmail.com
}

Received 16 April 2018; Accepted 3 June 2018; Published 30 June 2018

\begin{abstract}
Purposes: To explore the preference of various learning styles of university students, the possible impact of different learning styles on academic performance, and the possible variables which may influence students' academic performance in Glasgow, the UK. Methods: A case exploratory study approach where 40 university students (16 females and 24 males) both British and international ones with the age range (18-35) participated with filling in a self-completion questionnaire by convenience sampling. Results: The findings indicated that kinaesthetic learning style was males' learning style preference while females preferred using visual learning style; additionally, international students preferred using visual learning style whereas kinaesthetic learning style was British students' preference with learning style. Moreover, different learning styles affected academic performance due to different subjects. Kinaesthetic learning style had a better academic performance for engineering students, while visual learning style performed better for educational students. In terms of variables, age, gender and personality all might influence academic performance. Conclusions: Learning styles seem to be impacted by major of study, gender, personality, behavioural and experimental research may result into more credible evidences about the impact of learning styles on academic performance and also the possible differences between existing learning style and learning style preference as shown in our presented model (diagram 1).
\end{abstract}

Keywords: learning style; learning preference; academic performance; auditory learners; visual learners; kinaesthetic learners; VAK theory. 
Ли Ма ${ }^{1}$ Альдуайс Ахмед

ИССЛЕДОВАНИЕ СТИЛЕЙ ОБУЧЕНИЯ И ИХ ВОЗМОЖНОГО ВЛИЯНИЯ НА УСПЕВАЕМОСТЬ СТУДЕНТОВ УНИВЕРСИТЕТА В ГЛАЗГО

\author{
1) XUE Bang Education \\ Академический Научно-исследовательский центр, Кафедра К12 \\ Пекин, KHP, No. 19 Xinjiekou Wai St., 100875, Beijing, P.R.China \\ liangmuchengmiki@163.com \\ 2) Институт Международного и сравнительного образования \\ Факультет образования, Пекинский Педагогический Университет \\ Пекин, КHP, No. 19 Xinjiekou Wai St., 100875, Beijing, P.R.China \\ ibnalduais@gmail.com
}

Статья поступила 16 апреля 2018 г.; Принята 4 июня 2018 г.; Опубликована 30 июня 2018 г.

\begin{abstract}
Аннотация. Цели: изучить предпочтения различных стилей обучения студентов университетов, возможное влияние различных стилей обучения на успеваемость, а также возможные переменные, которые могут повлиять на успеваемость студентов в Глазго, Великобритания. Memodbl: экспериментальное исследование, в котором приняли участие 40 студентов университетов (16 женщин и 24 мужчины), как британских, так и международных, с возрастным диапазоном (18-35 лет), заполнив анкету для самостоятельного заполнения путем удобной выборки. Результаты: полученные данные показывают, что кинестетический стиль обучения предпочитают мужчины, в то время как женщины предпочитают использовать визуальный стиль обучения; кроме того, иностранные студенты предпочитают использовать визуальный стиль обучения, в то время как кинестетический стиль обучения предпочтителен для британских студентов. Кроме того, разные стили обучения повлияли на академическую успеваемость из-за разных предметов. Кинестетический стиль обучения имел более высокую академическую успеваемость для студентов-инженеров, тогда как стиль визуального обучения лучше для студентов образовательных учреждений. С точки зрения переменных, возраст, пол и личность могут влиять на успеваемость. Bblводы: на стили обучения, по-видимому, влияют основные исследования, гендерные, личностные, поведенческие и экспериментальные исследования могут привести к более достоверным доказательствам влияния стилей обучения на академическую успеваемость, а также к возможным различиям между существующим стилем обучения и предпочтением стиля обучения, как показано в нашей представленной модели (Диаграмма 1).
\end{abstract}

Ключевые слова: стиль обучения; предпочтение обучения; успеваемость; аудиалы; визуалы; кинестетики; теория ВАК.

Introduction. Learning styles should be matched to teaching styles and vice versa. In other words, there must be an integration between learning theories and teaching methodology - matching learning styles for the former and teaching styles for the latter! In this sense,
Alduais (2012a) stated '...learners learn what is learnable and teachers teach what is teachable' (p. 116). Alduais (ibid) proposed that using different types of aids (i.e. visual aids, audio aids, audio visual aids, action aids and multimedia aids) can be introduced as one solution 
to match the different learning styles by learners. Similarly, Alduais, (2012b) went on with this argument between matching teaching styles and learning styles where he assumed 'everyone's (i.e. teachers) method is entirely different from everyone's strategy' - referring to teaching strategies; and 'every learner's ability of understanding is also entirely different from another learner's ability of understanding' (p. 489). Further, (Alduais, 2013) listed at least ten advantages for the use of technology during teaching among which attracting yet maintaining learners' attention. He mentioned an example where (any) presented information for the learners is first presented to be heard (i.e. audio aids) and then visualised (i.e. visual aids), (pp. 5-6).

Over the past decades, learning style has become the significant main concern in the majority of sectors of education (Corbett and Smith, 1984: 212). Learning style is an important field of educational area (Shabani, 2012). Learning style as a particular pattern relates to different individuals' methods of acquiring information, learning strategies and learning preference (Esfandabad, 2010; Geisert and Dunn, 1991: 291). According to Geisert and Dunn (1991: 291), different indi- viduals could be influenced by various elements of learning styles which could have positive and negative effect on academic performance. More effective academic performance is contributed on types of learning styles (SIMS and Sims, 1995). Different learning styles could produce different levels academic performance (Komarraju et al, 2011). There could be a relationship between learning style and academic performance (Vermunt, 2005: 205). Therefore, the influence of various types of learning styles on academic achievement is necessary to be understood. There are many learning styles that have been identified by different researchers. For instance, seventy-one learning style models were presented by Coffield, Moseley, Hall, and Ecclestone (2004). One of these learning style models is the VAK theory. Learning Modality Model which is referred to VAK theory was originated by Barbe Swassing in 1979 and it basically assumes that learning takes places at three modalities visual, auditory and kinaesthetic (hereafter VAK) (Harrington-Atkinson, 2017 and Childress, 2003). The following diagram is an illustration for this model based on reading from (Harrington-Atkinson, 2017 and Childress, 2003). This model is an attempt to interpret the operation of this model.

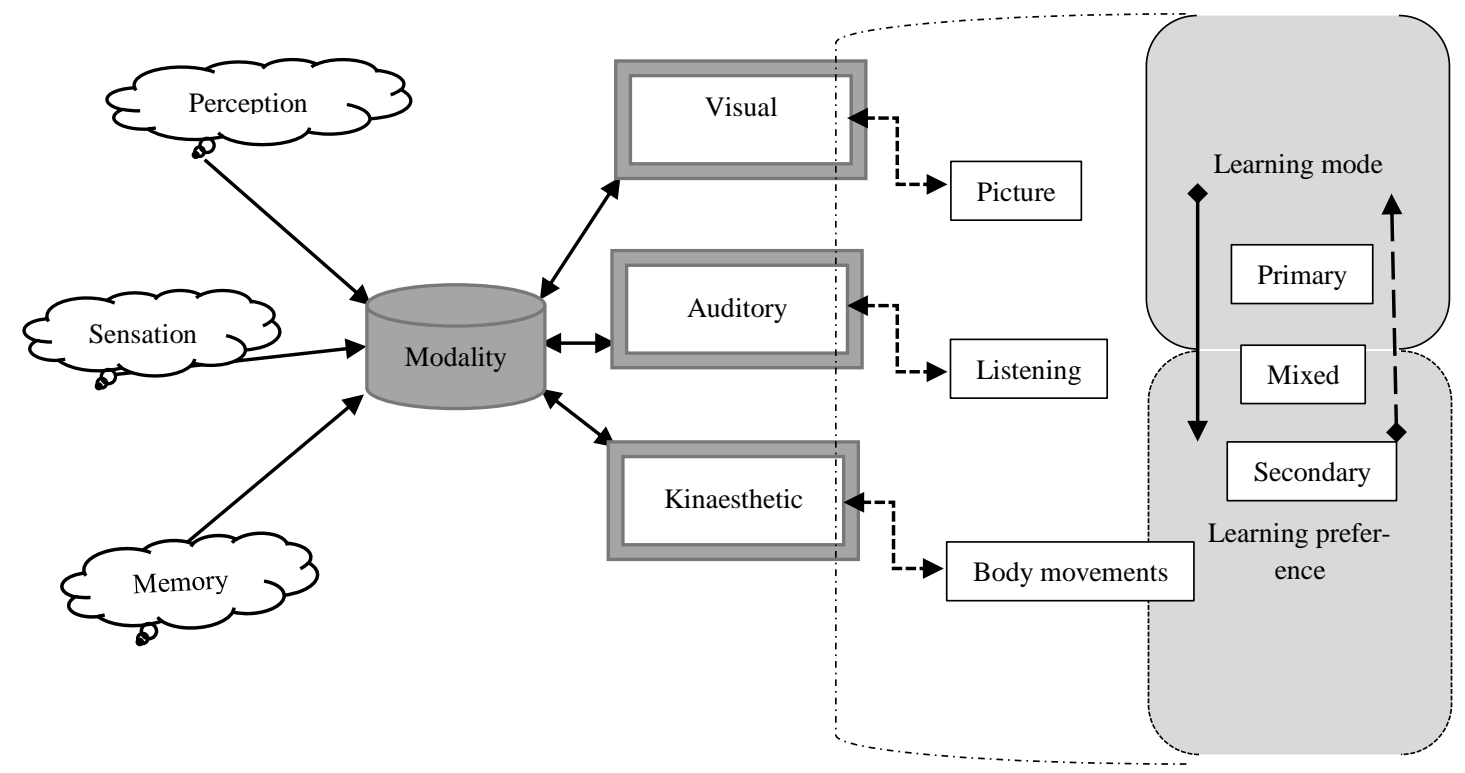

Fig. 1. VAK theory and learning modalities proposed model 
Several studies reported that there is no enough evidence indicating a significant effect on learners' performance based on individualisation of learning (e.g. Pashler, MacDaniel, Rohrer, and Bjork, 2008; Scott, 2010; Rohrer $\&$ Pashler, 2010). On the other hand, some reported researches indicated empirical evidence supporting the effect of individualised learning based on learning styles (e.g. Fleming, 1995) supporting the VAKR model, and (Manolis, Burns, Assudani, and Chinta, 2013) - supporting Kolb's model.

Given this, a major conflict among researchers worldwide is not the explanation of learning styles or if they do really exist; it is rather about finding enough evidence affecting learning when considering these learning styles regardless of the followed mode. Over the last few decades, a number of studies worldwide have explored various impacts of learning styles for students toward academic performance (Ozgur et al, 2012; Felder and Silverman, 1988; Koh and Chua, 2012; Phantharakphong, 2012; Umar and Hui, 2012). However, the majority previous studies has been mainly focused on some elements which influence students' academic performance, very few studies were focus on the relation between learning styles and academic performance. Thus, the following review is an account of this issues which are presented as per illustrated in the diagram below.

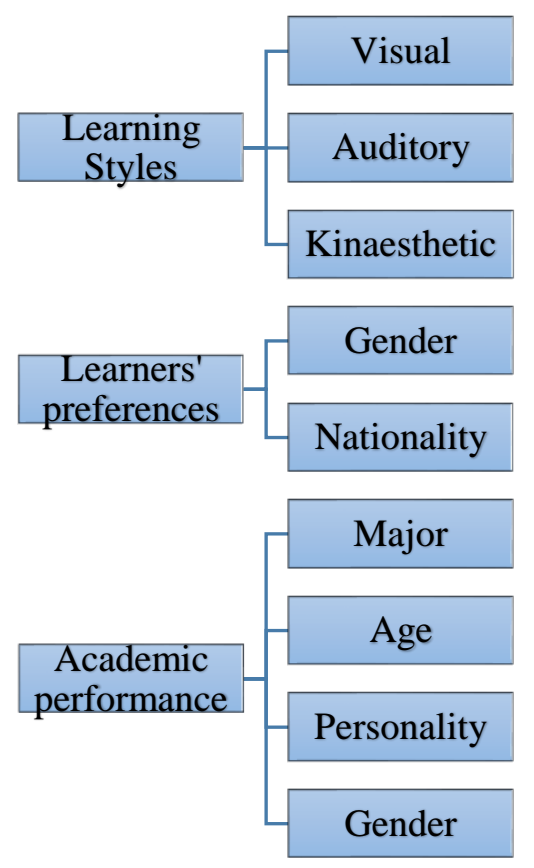

Fig. 2. Conceptual framework

To start with learning styles and as we introduced earlier with reference to the VAK theory, a learning style could be categorised into three main types: auditory, visual and kinaesthetic learning styles (Yildirim et al, 2007: 76; (Esfandabad, 2010; Geisert and Dunn, 1991; Felder and Silverman, 1988: 676). Different individuals could use different learning styles. Some students tend to be auditory learners, some are likely to be visual learners and others might use kinaesthetic learners (Willingham, 2005; Wehrwein et al, 2007). Auditory learners are likely to be good at hearing, including podcast, internal dialogue and external sounds; visual learners might be do well in seeing and reading diagrams, pictures, charts, symbols and so on; kinaesthetic learners tend to like to build models, do experiments in the lab, physical activities and so on (Surjono, 2011; Slater and Vsoh, 1993; Oflal, 2012).

As for learners' preferences, some previous studies showed that individuals have own learning style preferences such as visual learn- 
ing style, auditory learning style and kinaesthetic learning style. Students' learning style preference might be related to gender and nationality as reported by (Wehrwein et al, 2007; Honigsfeld, and Dunn, 2003; Ramburuth, and McCormick, 2001). Gender as a significant element influences the students' choice of different learning styles. There is a significant contrast between males and females. Honigsfeld and Dunn (2003) argued that males prefer using kinaesthetic learning style; whereas, females prefer choosing auditory learning styles. Moreover, nationality is also an element affects choice of students' learning style. Ramburuth, and McCormick (2001) pointed out that auditory learning style is an Australian students' preference while international students have no specific learning styles, it is so because preferences of international students are limited by social and cultural environment, pressure of study and tuition.

In this regard, many previous studies showed that both gender and nationality influence the students' learning style preference, and there are many limitations. One study was only focused on high school students while current research will investigate university students, university students might have a significant different result (Honigsfeld, and Dunn, 2003). Another study was only concentrated on undergraduate physiology students, the result may not be suitable in every subject, in addition, it sampled 86 students including 66 males and 20 females in Michigan State University, the sample size of different gender were not balanced, it should be added more females (Wehrwein et al, 2007). One of previous studies sampled 78 university students who learned English language course (Ramburuth, and McCormick, 2001). It could be hypothesised that Australian students whose first language is English, and they preferred auditory learning style due to the high level of listening skills, while international students whose English level are lower than native speakers, they may not find a suitable learning style so far, but because it sampled in Australia, it might not be applied in Glasgow but could provide a research orientation for current research.
The last part of this introduction is the effect of learning styles on academic performance. Different learning styles could lead to different effects towards academic performance (Ozgur et al, 2012; Felder and Silverman, 1988; Koh and Chua, 2012; Phantharakphong, 2012; Umar and Hui, 2012). Compared with visual learners and auditory learners, most engineering students prefer using kinaesthetic learning style and achieve a better performance (Felder and Silverman, 1988). It might be because mechanical engineering students need to build models and do laboratory experiments as assignments frequently (Felder and Silverman, 1988; Koh and Chua, 2012). Phantharakphong (2012) argued that auditory and visual students as high achievers perform much better on English course than kinaesthetic students, which only account for approximately 6\%. Additionally, Umar and Hui (2012) pointed out that visual students achieve higher performance than auditory and kinaesthetic students on computer course. It might be because computer course relates to visualization techniques (Umar and Hui, 2012). Some courses require specific learning skills, therefore students with preference for those learning style may perform better.

Many previous studies showed that various academic performances are influenced by different types of learners (Ozgur et al, 2012; Felder and Silverman, 1988; Koh and Chua, 2012; Phantharakphong, 2012; Umar and Hui, 2012). For instance, some studies were only focused on one particular subject such as engineering, English and computer courses (Felder and Silverman, 1988; Koh and Chua, 2012). It should be added more subjects to investigate, because different subjects may request different learning styles to achieve high performance (Felder and Silverman, 1988; Koh and Chua, 2012). Furthermore, some previous study sampled in the countries like Thailand and Malaysia which could not be applied in Glasgow (Phantharakphong, 2012) However, these previous studies were focused on university students which the age is suitable for current research. Although previous studies have limitations to current research, this will provide a research guidance to this research. 
Moreover, a number of previous studies also have discussed variables which influence university students' academic performance, including students' age, personality and gender. The age of students is one of the significant variables which affect students' academic performance (Reid, 1987: 95; Salamonson and Andrew, 2006). Reid (1987: 95) demonstrates that older students and young students who select the learning styles have different academic performance. Salamonson and Andrew (2006) pointed out that although some students use the same learning style, the majority of older students gain higher scores than the young students. Similarly, personality is considered to be one of the most important variables influencing students' academic performance (Wehrwein et al, 2007; Slater et al, 2007; Laidra, 2007: 129-135; Komarraju et al, 2011: 474); This research shows that individuals who are extroversion including openness, agreeableness and conscientiousness could achieve a higher score than neuroticism individuals. It might be hypothesised that openness high achievers are likely to have strong curiosity to be eager for further understanding; agreeableness individuals might because they have a positive attitude of cooperation which could improve academic performance; and conscientiousness students are likely to focus more on learning strategies and have a strong ethical attitude to approach assignments and exams (Komarraju et al, 2011: 474). Also, gender, as a variable might affect students' academic performance. Males and females tend to have different academic achievement (Ghazvini and Khajehpour, 2011; Fin and Ishak, 2012; Honigsfeld and Dunn, 2003). Ghazvini and Khajehpour (2011) pointed out that although some males and females use the same learning style due to the difference of some other elements including motivation, attitude, timemanagement, concentration, ability to select main points, the academic achievements could be different. For instance, females could be good at time-management and use self-testing well than males, and females could achieve a higher score than males.
That said, very few previous studies were focused on the university students in Glasgow; the ages of respondents of some previous studies are not suitable in current research (Reid, 1987: 95; Salamonson and Andrew, 2006; Wehrwein et al, 2007; Slater et al, 2007; Laidra, 2007: 129-135; Komarraju et al, 2011: 474); Some findings might be outdated, for example, Reid's work was published in 1987, some findings might be out of date (1987: 95). Another limitation is that the sample size of students is not balanced. For example, Komarraju et al (2011) sampled 308 undergraduate college students and approximately $80 \%$ freshmen and sophomores are participated whereas only $20 \%$ junior and senior students are investigated in this previous study. Thus the methodology may not be applied to current research, more junior and senior students should be added. In addition, academic record of different majors which investigated are not average score, in previous study, students may have different academic grades due to various majors, students who achieve a lower score might because they are not good at this major (Komarraju et al, 2011). Therefore, these previous studies might not be appropriate in Glasgow but could provide an orientation for current research. To conclude, three themes about effect of learning styles on academic performance have been discussed in this literature review. These previous studies about impact of learning styles which influences on students' academic performance are only focus on one particular subject and different countries which will not apply for this research. In addition, variables which affect students' academic performance is rarely focused on university students, sample size is not balanced and average score which examined is not from the same major. However, these previous studies provide valuable research orientation to current research. This research will attempt to bridge to gap.

The purpose of this research is to explore the impact of learning styles on academic performance among university students in Glasgow. This research is mainly focusing on the students' preference of various learning styles and the effects of different learning styles on 
academic performance. In addition, variables which influence university students' academic performance including age, gender and personality will be considered in this research.

1. What learning styles do university students prefer using in Glasgow?

2. What effects of different learning styles have on academic performance?

3. What are the main variables which influence university students' academic performance?
Methodology and methods. Sample. Probability sampling might be more effective to this research but it is impossible to access the whole population in all the university students in Glasgow due to time and resource constraints (Saunders et al, 2012). Considering convenience, a non-probabilities sampling technique was implemented in this research. The following diagram illustrates the sampling framework including: theoretical population, study population, sampling frame, and the sample.

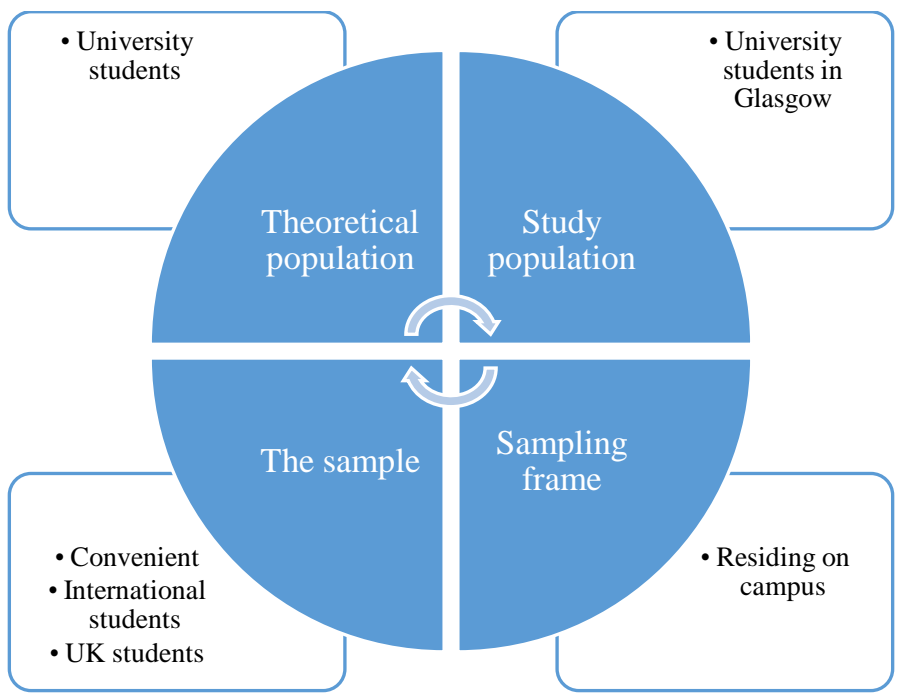

Fig. 3. Sampling framework

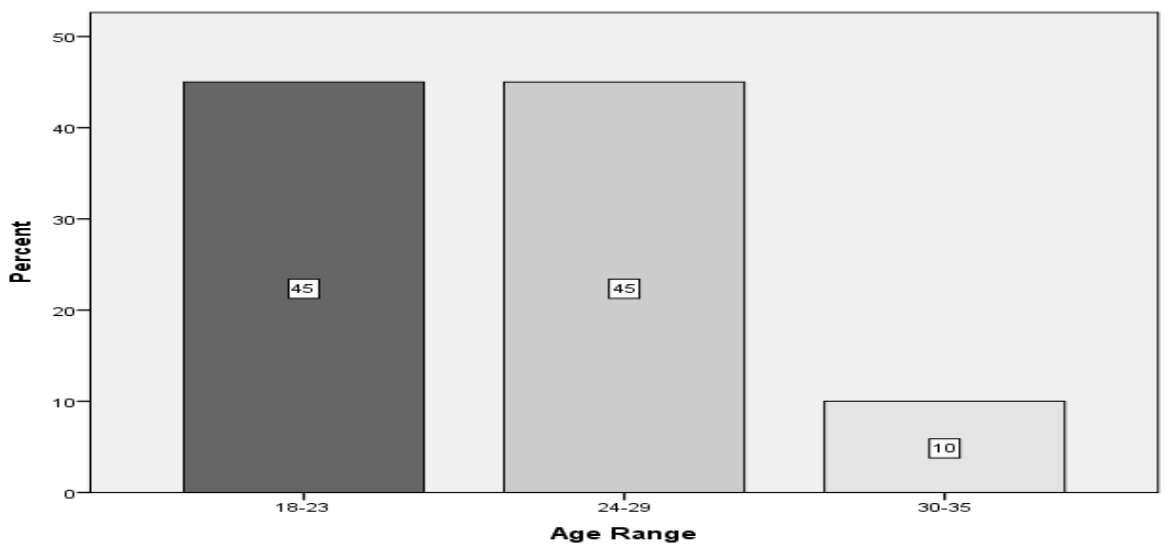

Fig. 4. Percentages of participants divided by age range 


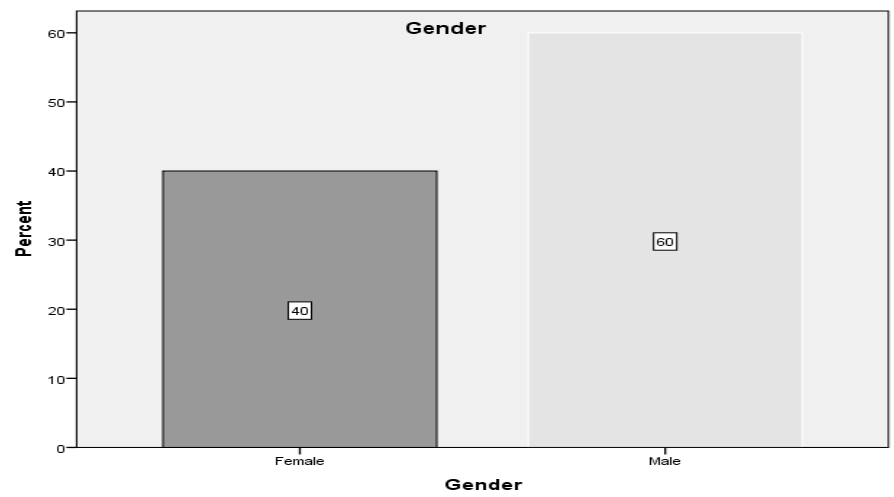

Fig. 5. Percentages of participants divided by gender

Therefore, this research selected participants conveniently, and classified by age and gender. Figure 1 shows that the research's sample size was 40 participants in total, the numbers of males and females are 24 and 16 respectively, the age group between 18 and 23 are almost the same with the age group between 24 and 29, and both these two groups totally account for $87.5 \%$ among the whole age group. However, only 4 participants were investigated in 30-35 age group.

According to Golafshani (Golafshani, 2003: 603), validity for quantitative study requires statistical generalization in order to explore more situations and wider groups. Although sample size might not represent all the situations and may not generalize findings widely, we consider this study as a pilot study towards larger sample studies at one hand, and towards behavioural and experimental studies, on the other hand.

Measures. This study is implemented as an exploratory research, and the aim of this research is to examine students' preference of various learning styles, different learning styles effects on academic performance and variables including age, gender and personality which influence students' academic performance. In order to investigate effects of learning styles of university students in Glasgow, using survey strategy for this research will be suitable (Vermunt, 2005: 234). Both quantitative and qualitative data were collected by the researcher-made questionnaire, because questionnaire is an efficient and wide way to collect quantitative data and qualitative data within the survey strategy (Saunders et al, 2012: 417).
In order to collect quantity data, selfcompletion questionnaire (can be found in Appendix 1) through face to face was designed. There are totally twelve questions (the full questionnaire can be found in Appendix 1) including eleven categorical questions for testing gender, learning style preference of individuals, individuals' personality with multiple choice questions, and two numerical questions about age and students' average score range. Such as "What range of your average score you have currently in Glasgow?". The questionnaire was completed by respondents (males and females) who are all over 18 years old of universities and Glasgow International College in Glasgow.

For the purpose of this study, only two types of construct validity were evidenced, namely, face validity and content validity. This was motivated by the fact that some participants who did not answer all questions might feel confused and uncertain and even uncomfortable due to some questions were made ambiguous and less confidential. Therefore, 2 tutors and 3 classmates in Glasgow International College piloted and detected these questions. After piloting, a sensitive question about asking age directly was changed to multiplechoice which were given a range of age.

In terms of collecting qualitative data, an open question was used on the last section of the questionnaire to explore other different elements which influence academic performance except learning style (Bryman, 2008).

Design. A non-experimental design was used in this study which can be depicted in a notional form as follows: 
$\mathrm{N}$

$\mathrm{O}$

where:

$\mathrm{N}=$ non-equivalent assignment of the participants and group

$\mathrm{O}=$ learning styles questionnaire

Procedures. The questionnaires were given out in Glasgow on 25 June in 2014, and data was collected between 25 June and 4 July in 2014, by face-to-face. Because the first researcher was studying at Glasgow International College, she selected 23 students randomly at this college, 17 students were collected at Glasgow University including 11 British students.

Ethical consideration is an essential aspect during the application of research (Saunders et al, 2012: 208). In this research, both quantitative and qualitative data were collected in a confidential and anonymous way, the questionnaire retains participants' anonymity. Participants had right to withdraw if they felt uncomfortable (Boyle et al, 2003: 282). In addition, participants agreed to fill the informed form and informed consent were obtained by every participant (letter of consent can be found in Appendix 2). Such ethical and sensitive issues including confidentiality and privacy could be avoided in this method in order to provide a secure environment and guarantee the participants who gave the data confidentially and anonymously.

The threat of reliability and validity had considered in this research (Saunders et al, 2012: 193). During the progress of data collection, some problems were prevented the progress of collecting data due to some reliability threats. For example, the researcher asked a student to complete the questionnaire at the lunch time in the Fraser Building at Glasgow University, but this student rejected due to this student was in a hurry to class and did not have sufficient time to complete the questionnaire. Therefore, this research chose to collect data at weekend because the majority of people would have sufficient time to finish the questionnaire. Furthermore, this research selected several secure place including library of Glasgow University, Fraser Building at Glasgow University, campus of Glasgow University to conduct. In addition, the questionnaire for some participants took them away and filled in own time, it could gain a true answer from respondents to avoid adversely influence the way of participants perform.

\section{Research Results and Discussion.}

Three questions were raised in this paper. They included:

1. What learning styles do university students prefer using in Glasgow?

2. What effects of different learning styles have on academic performance?

3 . What are the main variables which influence university students' academic performance?

The collected data is presented to answer these questions by order. The researchers used SPSS 21 Version to analyse the collected data. For the purposes of this study, only descriptive statistical tools were used to analyse the collected data.

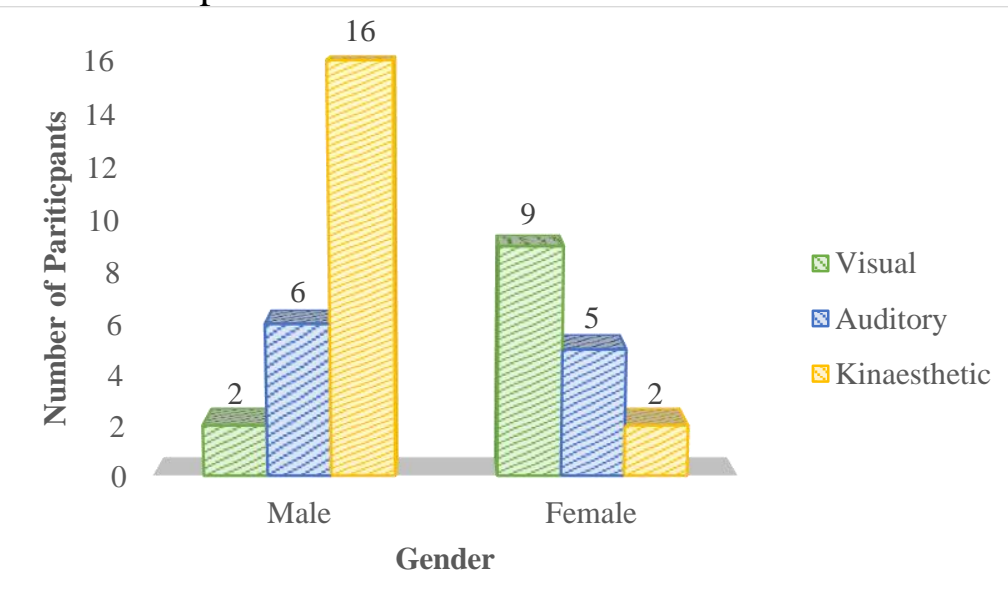

Fig. 6. Learning styles preferences divided by gender 
Figure (6) and with reference to the questionnaire, three multiple-choice questions were asked about which learning styles individuals prefer by giving some specific examples related to visual, auditory and kinaesthetic learning styles. As shown in Figure 2, males preferred using kinaesthetic learning style which accounted for more than a half $(16,67 \%)$ while there were only 2 out of $24(8 \%)$ participants selected visual learning style. In summary, kinaesthetic learning styles preference are much more than visual and auditory learning style among males. In contract, as can be seen from Figure 3, female students preferred choosing visual learning style and auditory learning style both much more than kinaesthetic learning style. The most females liked using visual learning style which made up more than a half $(56 \%)$ while kinaesthetic learning style only accounted for $13 \%$. The most interesting finding was that auditory learning style account for $31 \%$ which was the second preference for females. In conclusion, visual learning style was females' preferential choice. In conclusion, as can been seen, kinaesthetic learning style is males' first preference while females preferred using visual learning style. There was an interesting finding was that auditory learning style was both males and females second preference, but females used auditory learning style more than males.

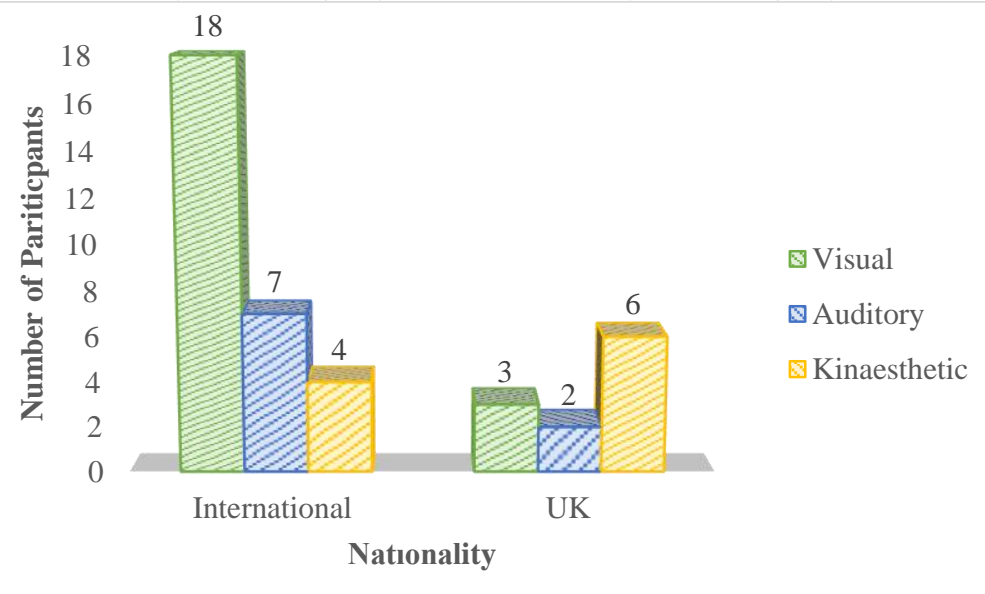

Fig. 7. Learning styles compared between international and UK students

This research was divided into two types of nationalities: international students and British students. There are 29 international students and 11 British students respectively. As can be seen from Figure (7), international students preferred using visual learning style than British students. Obviously, 18 out of 29 selected visual learning style which account for $62 \%$ while very few British students (27\%) chose visual learning style. In summary, visual learning style was international students' preference. Moreover, Figure (8) provides that preference of auditory learning style among university students, it can be seen that, international students preferred using auditory learning style which accounted for approximately 24\%. Compared with international students, there were only 2 chose auditory learning style which make up $18 \%$ among the British students. Surprisingly, it was found that international students used auditory learning style more than British students. Finally, as shown in this figure, only $14 \%$ (4 students) International students preferred using kinaesthetic learning style while the British students made up more than a half (54\%). In summary, the result of this bar chart showed that the British students preferred using kinaesthetic learning style than international students. In summary, these three figures showed that international students preferred using visual learning style, while very few international students used kinaesthetic learning style among 29 respondents. For British students, there are totally 11 respondents in this research investigation, it still can be seen that British students regarded kinaesthetic learning style as the first preference. 


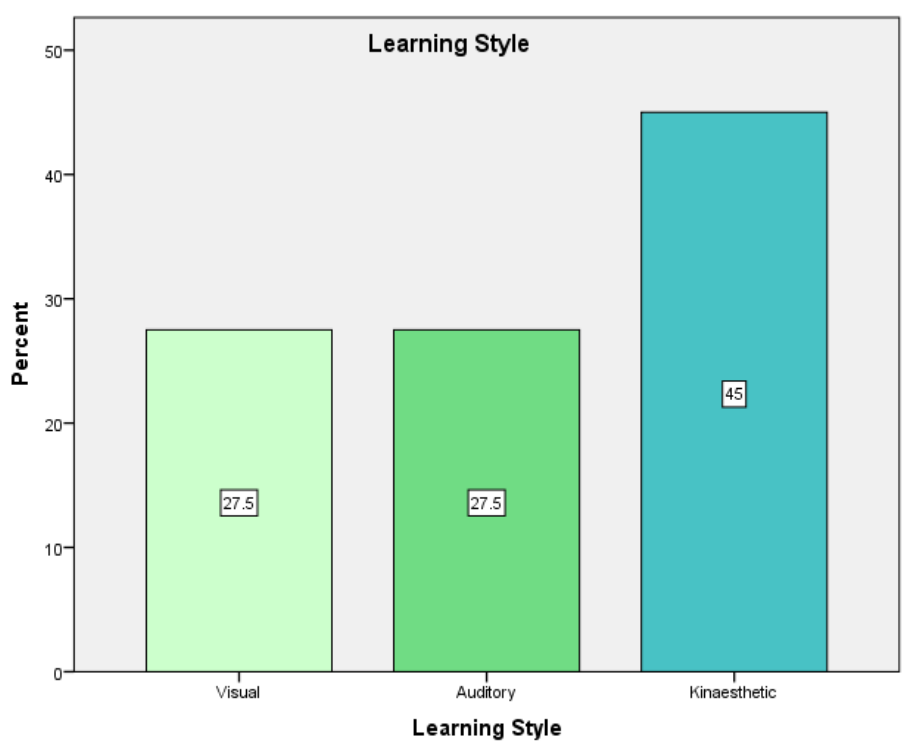

Fig. 8. Percentages of learning styles when they are calculated by gender for all the participants

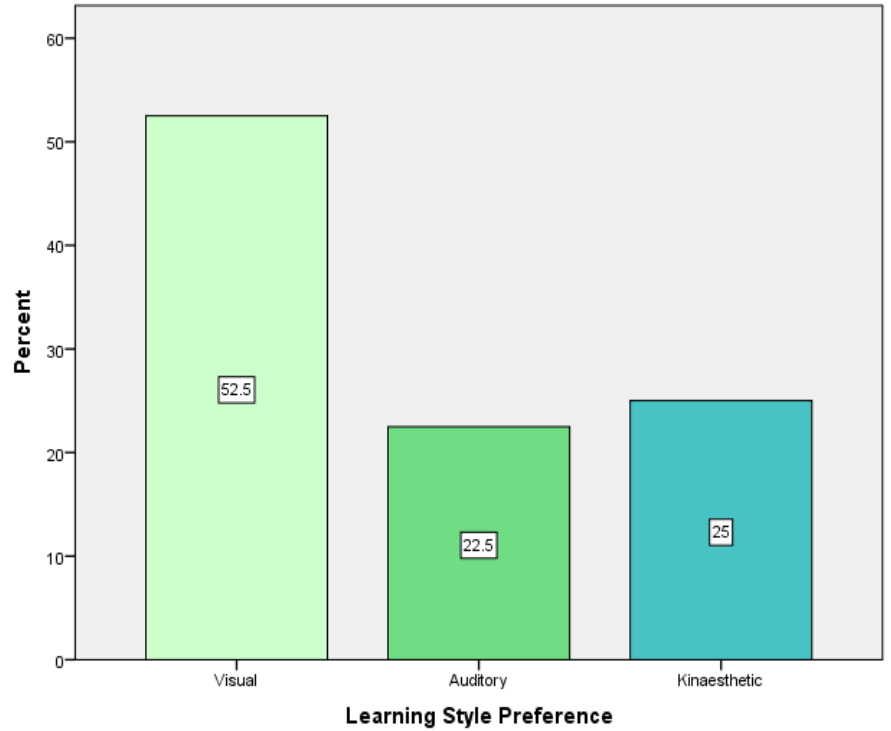

Fig. 9. Percentages of learning styles when they are calculated by nationality and learning style type for all the participants

Figures 5-6 present the possible impact of different variables on the output of learning styles when calculated using different bases. For instance, in Figure (5) the percentages among the three learning styles for the 40 participants were calculated based on gender and it showed kinaesthetic learning as the number one preferred learning style with $(45 \%)$ as compared to only (27.5) for each visual and auditory learning styles. On the other hand, when the calculation are reversed based on the learning style type and nationality, visual learning style is the number one with over $(52 \%)$ followed by the kinaesthetic learning style but with significant different between the two only $(25 \%)$ of students are within this learning style. For one reason or another which beyond the scope of this paper, learning styles preferences seem to be impacted by predefined variables and this could be attributed to the used measure in this study (a researcher-made questionnaire).

In this regard, the effects of different learning styles on academic performance was asked "What subject do you study" by multiple-choice by self-report of respondents, and these findings also related with the multiplechoice were asked about what learning styles 
students prefer using by some examples about visual, auditory and kinaesthetic learning styles. There are 40 respondents participated in this research, however, current research was mainly focus on 30 students $(75 \%)$ which were studying Engineering and Education. The 10 left students had a wide range subjects, therefore, they were excluded in this section.

Table 1

Average score of different learning styles by two subjects

\begin{tabular}{|c|c|c|c|}
\hline Subject & Learning style & No. of participants & Mean (Average score) \\
\hline \multirow{3}{*}{ Engineering } & Visual & 3 & $52.7 \sim 56.7$ \\
\cline { 2 - 4 } & Auditory & 4 & $54 \sim 58$ \\
\cline { 2 - 4 } & Kinaesthetic & 10 & $62.1 \sim 66.1$ \\
\hline \multirow{3}{*}{ Education } & Visual & 7 & $66 \sim 70$ \\
\cline { 2 - 4 } & Auditory & 3 & $56 \sim 60$ \\
\cline { 2 - 4 } & Kinaesthetic & 3 & $51 \sim 55$ \\
\hline
\end{tabular}

As can be seen from Table (1), engineering students with kinaesthetic learning styles have a higher score $(62.1 \sim 66.1)$, while the mean of visual and auditory learning styles are similar which were both less than 60 . Educational students with a higher score (66 70) preferred using visual learning style.

Average score of academic performance by age and gender

\begin{tabular}{|c|c|c|}
\hline Variables & No. of participants & Mean (Average score) \\
\hline Age & 40 & $55.1 \sim 59.1$ \\
\hline $18-23$ year & 18 & $63.3 \sim 67.3$ \\
\hline $24-29$ year & 18 & $56.0 \sim 60.0$ \\
\hline $30-35$ year & 4 & \\
\hline Gender & 40 & $60.4 \sim 64.4$ \\
\hline Male & 24 & $56.9 \sim 60.9$ \\
\hline Female & 16 & \\
\hline
\end{tabular}

Variables including age, gender and personality were asked about "What is your age range?", "What is your gender?" and three questions about exploring individuals' personality through some specific example options. Table (2) shows 24-29 age group achieved a high average score range $(63.3 \sim 67.3)$ compared with the other two age groups. 18-23 age group and 30-35 age group have a very similar average score around 55 60, and the mean of the youngest group slightly lower than the old group. Additionally, males' average score range (60.4 64.4) was more than females' (56.9 60.9). In summary, the two older age groups had a better academic performance than the youngest age group. Males had a better academic performance than females.

This research was divided into two major types of personality: Extroversion and Introversion. As can be seen from Table (2), 23 respondents out of 40 were participants who was the high average score range groups (62.8 66.8) due to extroversion personality, while there were 17 participants who were introverted achieved a lower average score range (53.6 57.6). The results of this study indicate that extroverted students performed much better than introverted students.

Table 3

Average score of academic performance by individuals' personality

\begin{tabular}{|c|c|c|}
\hline Variable & No. of participants & Mean (Average score) \\
\hline Personality & 40 & $62.8 \sim 66.8$ \\
\hline Extroversion & 23 & $53.6 \sim 57.6$ \\
\hline Introversion & 17 & \\
\hline
\end{tabular}




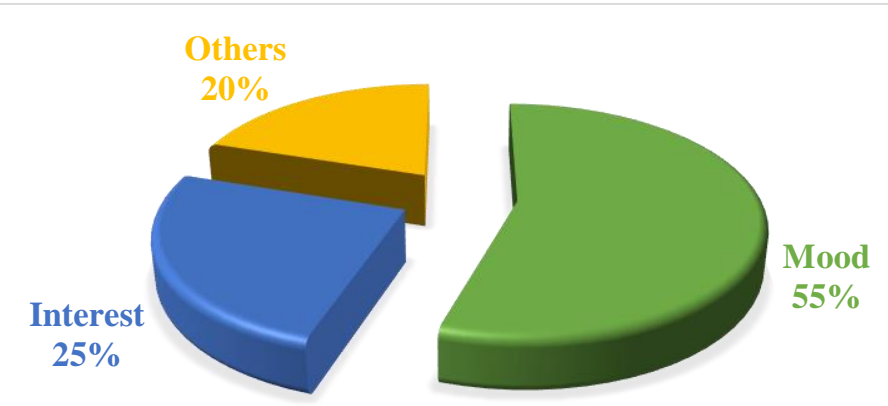

Fig. 10. Percentages of responses for what other factors could affect academic performance

Participants were asked about other elements affect students' academic performance by using an open question, and there are $92.5 \%$ (37 out of 40) answered this question. As Figure (10) shown, there was an interesting finding was that there were $22(44 \%)$ respondents regarded mood as an important element affected their academic achievement. Another finding can be found that 10 (36\%) respondents thought interest influenced academic performance. And the rest of respondents which had different answers were difficult to find out other results. In conclusion, the result of this open question can be found that mood and interest are two important elements which influence students' academic performance.

Discussion. Since our study is not experimental so the results certainly provide answers to our raised questions. These answers are in agreement and disagreement with some previous reported research.

First, the students were found that males prefer using kinaesthetic learning style whereas females like choosing visual learning style in Glasgow. The result of males' learning style preference was kinaesthetic which is similar to that Honigsfeld and Dunn (2003)'s study undertaken in Michigan State University. This fit with some previous studies conducted by Honigsfeld and Dunn (2003) and Ramburuth and McCormick (2001). However, this finding was unexpected and suggests that females' learning style preference was visual learning style in Glasgow rather than auditory learning style. This may be because the majority of fe- male respondents' major was education in current research, visual learning style is more suitable for educational students. Furthermore, this result could be because the females' sample size was smaller than males' in this research, the results might be different if could find more females.

Second, another finding suggests that the British students preferred using kinaesthetic learning style while international students preferred using visual learning style in Glasgow which were different with previous study of Ramburuth and McCormick (2001)' s study. In this research, there were totally 11 British respondents and most of respondents study engineering which require kinaesthetic learning style, also the sample size was quite small in this research which was difficult to find systematic variation. However, 29 international students were participated, it might be hypothesised that the result of international students' learning style preference was visual learning style due to the most students' major were education, law, economic and psychology which these subjects required visual learning skill (Koh and Chua, 2012).

Third, kinaesthetic learning style performed much better on academic achievement (62.1 66.1) for engineering students than students who chose visual and auditory learning styles. This result is consistent with that from Felder and Silverman (1988) and Koh and Chua (2012)' studies. In addition, the research showed that this result of visual learning style achieved a better academic performance than the other two learning styles for educational 
students. This result is similar to previous studies which conducted by Phantharakphong (2012) and Umar and Hui (2012). More specific, although current research mainly focused on engineering students and education students who were different with the objects (engineering, English course and computer students) of previous studies, the finding was that different learning styles affect different academic performance according to different subjects. Students who had a good academic performance due to the learning style suit their subjects, the result is similar to previous studies.

Fourth, in this research, university students in Glasgow were found that age, gender and personality might influence their academic performance, and this related to previous studies (Reid, 1987: 95; Salamonson and Andrew, 2006; Wehrwein et al, 2007; Slater et al, 2007; Laidra, 2007: 129-135). For age, the 24-29 age group and 30-35 age group had a better academic performance than 18-23 age group, this result indicated that the older age group achieved a higher score than the youngest group which is similar to previous studies. However, 24-29 age group was the highest achiever rather than the oldest age group (3035 year) among these three age groups, this might because the sample size of 30-35 year age group was quite small. In terms of gender, one unanticipated finding was that males (60.4 64.4) performed much better on academic performance than females' academic performance (56.9 60.9). This could be the males' sample size was bigger than females'. This result was contradictory with previous studies. Therefore, this research should find more female participants and balance the sample size between males and females, it might have a significant change.

Fifth, personality as an important variable influenced students' academic performance. There was a similarity between current study and previous studies which conducted by Laidra (2007: 129-135) and Komarraju et al, (2011). This finding showed that extrovert students had a much better academic performance (62.8 66.8) than introvert students (53.6 57.6), and this finding is consistent with such study.
Conclusion. This research attempted exploring the preference of various students' learning style, the possible impact of different learning styles on academic performance, and variables which influence university students' academic performance. The findings showed that males preferred using kinaesthetic learning style while females chose visual learning styles as first preference. Additionally, auditory learning style was both males and females second preference. Also, in terms of nationality, international students preferred visual learning style while British learning style preferred using kinaesthetic learning style. Moreover, different learning styles had different academic performance due to different subjects require specific learning styles. Finally, variables such as age, gender and personality influence students' academic performance directly. In this research, there is an implication is that, in order to achieve a high mark students should select own suitable learning style according different subjects .

Limitations. Our research has some limitations. Firstly, due to this study used a nonprobabilities sampling technique, the sample size was small which did not represent the whole population. Secondly, the sample was conducted only 40 participants by self-completion questionnaire, even did not include interview. Some answers may not be accurate. Lastly, due to time and resource constraints, this research was only focus on one international college and one university in Glasgow.

Future Research. Future research need to enlarge the sample size in order to gain more reliable answers and findings. Additionally, this study also need to examine more universities in Glasgow in order to make the data more reliable and accurate. The measures should also include subjective and objectives ones. In other words, even the used measure here evidenced only two types of construct validity (the minor ones: face and content validities) and none of the reliability types was measured before using this measure. Besides, the use of the words impact, influence were much more suitable with experimental and behavioural re- 
search as the collected evidence here was totally subjective and cannot really yet scientifically measure the 'impact' of something on something else. Besides, the sampling was not matched or paired which made the comparisons and drawn results weaker. All these issues should be considered for future researches on learning styles.

\section{References}

1. Alduais, A. M. (2012a), "Integration of language learning theories and aids used for Language teaching and learning: A psycholinguistic perspective", Journal of Studies in Education, 2 (4), 108-121.

2. Alduais, A. M. (2012b), "An account of teaching strategies which promote student-initiation”, Journal of Sociological Research, 3 (2), 489-501.

3. Alduais, A. M. (2013), Language and Technology Use: An introductory course for using aids to teach and learn language components and language skills, in Seetaram, N. (ed.), Lambert Academic Publishing LAP, Saarbrucken, Germany.

4. Boyle, E. A., Duffy, T. and Dunleavy, K. (2003), "Learning styles and academic outcome: The validity and utility of Vermunt's Inventory of Learning Styles in a British higher education setting", British Journal of Educational Psychology, 73(2), 267-290.

5. Bryman, A. (2008), Social Research Methods, Oxford University Press, Oxford, UK.

6. Childress, M. (2003), Educational Implications Of Three Models Of Learning.

7. Coffield, F., Moseley, D., Hall, E., and Ecclestone, K. (2004), Learning styles and pedagogy in post-16 learning: A systematic and critical review.

8. Corbett, S. S. and Smith, W. F. (1984), "Identifying student learning styles: proceed with caution!", The modern language journal, 68 (3), 212-221.

9. Esfandabad, H. S. (2010), "A comparative study of learning styles among monolingual (Persian) and bilingual (Turkish-Persian) secondary school students", Procedia-Social and Behavioral Sciences, 5, 2419-2422.

10. Felder, R. M. and Silverman, L. K. (1988), "Learning and teaching styles in engineering education", Engineering education, 78(7), 674-681.

11. Fin, L. S. and Ishak, Z. (2012), "A Priori Model of Students' Academic Achievement:
The Effect of Gender as Moderator", Procedia-Social and Behavioral Sciences, 65, 1092-1100.

12. Fleming, N. D. (1995), "I'm different; not dumb. Modes of presentation (VARK) in the tertiary classroom", Research and Development in Higher Education, Proceedings of the 1995 Annual Conference of the Higher Education and Research Development Society of Australasia (HERDSA), Australia, July, Vol. 18, 308-313.

13. Geisert, G., and Dunn, R. (1991), "Effective use of computers: Assignments based on individual learning style", The Clearing House, 64 (4), 219-224.

14. Ghazvini, S. D., and Khajehpour, M. (2011), "Gender differences in factors affecting academic performance of high school students", Procedia-Social and Behavioral Sciences, 15, 10401045.

15. Golafshani, N. (2003), Understanding Reliability and Validity in Qualitative Research. The Qualitative Report, 8 (4), 597-607.

16. Harrington-Atkinson, T. (2017), Barbe's VAK Learning Style, available at: http://tracyharringtonatkinson.com/barbes-vaklearning-style (Accessed 31 December 2017).

17. Honigsfeld, A., and Dunn, R. (2003), "High school male and female learning-style similarities and differences in diverse nations", The Journal of Educational Research, 96 (4), 195-206.

18. Koh, Y. Y., and Chua, Y. L. (2012), "The Study of Learning Styles among Mechanical Engineering Students from Different Institutions in Malaysia", Procedia-Social and Behavioral Sciences, 56, 636-642.

19. Komarraju, M., Karau, S. J., Schmeck, R. R., and Avdic, A. (2011), "The Big Five personality traits, learning styles, and academic achievement", Personality and Individual Differences, 51 (4), 472-477.

20. Laidra, K. (2007), "The relation between learning styles: the big five personality traits and achievement motivation in higher education", Personality and Individual Differences, 26 (1), 129-140.

21. Manolis, C., Burns, D. J., Assudani, R., and Chinta, R. (2013), "Assessing experiential learning styles: A methodological reconstruction and validation of the Kolb Learning Style Inventory", Learning and individual differences, 23, 44-52.

22. Ozgur, S. D., Temel, S. and Yilmaz, A. (2012), "The effect of learning styles of preserve chemistry teachers on their perceptions of problem 
solving skills and problem solving achievements", Social and behavioral sciences, 46 (1), 1450-1454.

23. Pashler, H., McDaniel, M., Rohrer, D., and Bjork, R. (2008), "Learning styles: Concepts and evidence", Psychological science in the public interest, 9 (3), 105-119.

24. Phantharakphong, P. (2012), "English learning styles of high and low performance students of the faculty of education, Khon Kaen University", Procedia-Social and Behavioral Sciences, 46, 3390-3394.

25. Ramburuth, P., and McCormick, J. (2001), "Learning diversity in higher education: A comparative study of Asian international and Australian students", Higher education, 42 (3), 333-350.

26. Reid, J. M. (1987), "The learning style preferences of ESL students", TESOL quarterly, 21 (1), 87-111.

27. Rohrer, D., and Pashler, H. (2012), "Learning Styles: Where's the Evidence?", Online Submission, 46 (7), 634-635.

28. Salamonson, Y., and Andrew, S. (2006), "Academic performance in nursing students: influence of part-time employment, age and ethnicity", Journal of Advanced Nursing, 55 (3), 342-349.

29. Saunders, M., Lewis, P. and Thornhill, A. (2012), Research Methods for Business Students, Sixth Edition, Pearson Educated Limited, Essex, England.

30. Scott, C. (2010), "The enduring appeal of 'learning styles'", Australian Journal of Education, 54 (1), 5-17.
31. Shabani, M. B. (2012), "Different Learning Style Preference of Male and Female Iranian Non-academic EFL learners", English Language Teaching, 5(9), 127.

32. Sims, R., and Sims, S. (1995), The importance of learning styles: Understanding the implications for learning, course design, and education, ABC-CLIO.

33. Slater, J. A., Lujan, H. L., and DiCarlo, S. E. (2007), "Does gender influence learning style preferences of first-year medical students?", Advances in Physiology Education, 31 (4), 336-342.

34. Umar, I. N., and Hui, T. H. (2012), "Learning style, metaphor and pair programming: Do they influence performance?", Procedia-Social and Behavioral Sciences, 46, 5603-5609.

35. Vermunt, J. D. (2005), "Relations between student learning patterns and personal and contextual and academic performance", High Education, 49 (3), 205-234.

36. Wehrwein, E. A., Lujan, H. L., and DiCarlo, S. E. (2007), "Gender differences in learning style preferences among undergraduate physiology students", Advances in Physiology Education, 31 (2), 153-157.

37. Willingham, D. T. (2005), "Do visual, auditory, and kinesthetic learners need visual, auditory, and kinesthetic instruction", American Educator, 29 (2), 31-35.

38. Yildirim, O., Acar, A. C., Bull, S. and Sevinc, L. (2007), "Relationship between teachers' perceived leadership style, students' learning style and academic achievement: a study on high school students", Education Psychology, 28 (1), 73-81.

\section{Questionnaire}

Appendix

Thank you for agreeing to complete this questionnaire. The purpose is to find university students' learning styles towards academic performance in Glasgow and explore factors influencing them. Hence, please feel relax to answer these questions, and this questionnaire is totally anonymous.

\section{Part I: Personal Information \\ 1. What is your gender? \\ ○ Male o Female}

2. What is your age?

$\circ$ 18-23 ○ 24-29 ○ 30-35

3. What is your nationality?

$\circ$ British $\circ$ Russia $\circ$ Chinese

$\circ$ Korean $\circ$ Japanese $\circ$ Mexico 
o Others (Please write down your own answer)

4. What best describes your current education level?

○ Undergraduate student (including foundation)

$\circ$ Postgraduate student (including pre-master)

○ PHD

\section{Part II: Preference of students' learning styles}

1. When learning a new skill you prefer:

o watching what the teacher is doing

o talking through with the teacher exactly what I am supposed to do

$\circ$ giving it a try and work it out as I go along by doing it

2. If you were buying a new car, you would:

$\circ$ read reviews in newspapers and magazines

$\circ$ discuss what I need with my friends

$\circ$ test-drive lots of different types

3. When you have to revise for an exam, you generally:

$\circ$ write lots of revision notes and diagrams

o talk over my notes, alone or with other people

$\circ$ imagine making the movement or creating the formula

Part III: Variables and effects of learning styles on academic performance

1. What subject do you study?

$\circ$ Education $\circ$ Law $\circ$ Economic

$\circ$ Mechanical Engineering $\circ$ others (Please write down your own answer)

2. When you are taught new and fresh knowledge,

$\circ$ You feel afraid to accept new knowledge

- You feel neutral to learn new knowledge

$\circ$ You feel curious to new knowledge and want to explore deeper understanding of it

3. When you have some learning problems, you prefer:

o study and solve it alone

$\circ$ discuss in group and brainstorm to solve

4. When you have some difficulties you cannot solve immediately during your study, you will think:

$\circ$ It is impossible for me to do it and escape it

$\circ$ It is difficult but still have to do it

$\circ$ It is a good challenge for me to solve and want to carry on

5. What range of your average score you have currently? (in Glasgow)

$\circ<40 \circ 40 \sim 45 \circ 46-50 \circ 51-55 \circ 56-60$

$\circ 61-65 \circ 66-70 \circ 71-75 \circ 76+$

6. Except learning style, what other elements affect your academic performance? 
Конфликты интересов: у авторов нет конфликта интересов для декларации. Conflicts of Interest: The authors have no conflict of interest to declare.

Ma Li, XUE Bang Education, Academic Research and Development Centre, K12 Department
Beijing, P.R. China, No. 19 Xinjiekou Wai St., 100875, Beijing, P.R.China

Ahmed Alduais, Institute of International \& Comparative Education Faculty of Education, Beijing Normal University (BNU), Beijing, P.R. China 